\title{
Arctic Fisheries and International Law: Gaps and Options to Address Them
}

\author{
Erik J. Molenaar*
}

Global climate change has led to decreasing sea-ice coverage in the marine Arctic. This may facilitate an intensification of fishing in existing fishing areas as well as a fisheries expansion into new areas. This article provides an overview of the current international law relating to Arctic fisheries, identifies gaps therein that have become apparent due to climate change, and examines potential options to address some of these gaps. Particular attention is devoted to potential options for the international regulation of Arctic Ocean fisheries, whether through the Arctic Council, the Arctic Council System or by means of a stand-alone negotiation-process culminating in a stand-alone instrument on the (Central) Arctic Ocean.

\section{Introduction}

As has been extensively documented already, global climate change has triggered unparalleled change in the Arctic, including decreasing sea-ice coverage. This change will facilitate an expansion and intensification of existing maritime uses in the marine Arctic and the commencement of new maritime uses. Marine capture fisheries are among these. Fishing could intensify in existing fishing areas and expand into areas where marine capture fisheries have not yet taken place. According to some commentators, however, in the short term it is unlikely that abundance of fish stocks in the high seas portion of the Arctic Ocean (see definitions below) will allow for commercially viable fisheries. ${ }^{1}$ Others point to Arctic cod (Boreogadus saida), which has a circumpolar distribution both inshore and offshore, and may be highly abundant in view of the pivotal

\footnotetext{
* Senior Research Associate, Netherlands Institute for the Law of the Sea (NILOS), Utrecht University \& Adjunct Professor, University of Tromsø. Writing this article was facilitated by funding from the Netherlands Polar Programme and the Research Council of Norway. The author is very grateful for comments on earlier drafts and assistance received by Betsy Baker, Scott Highleyman, Timo Koivurova Ted McDorman, Inuuteq Holm Olsen, Andrew Serdy and Yoshi Takei.

1 Cf. Alf Håkon Hoel, "Living Marine Resources in the Arctic. Trends \& Opportunities", presentation held at the $2^{\text {nd }}$ Arctic
}

role it plays at the bottom of the Arctic marine ecosystem. ${ }^{2}$

This article focuses on ways to adapt international law on Arctic fisheries to climate change. Which gaps in this body of international law have become apparent due to climate change, and what are potential options to address these gaps? At the national level, reference can be made to the decision by the United States to prohibit commercial fishing in the exclusive economic zone (EEZ) off the coast of Alaska in the Arctic Ocean "until information improves so that fishing can be conducted sustainably and with due concern to other ecosystem components." This decision was motivated in part by a desire to "distinguish, where feasible, the separate effects of fishing and climate on biological populations." $^{4}$

The following discussion provides an overview of "Relevant International Fora and Instruments"

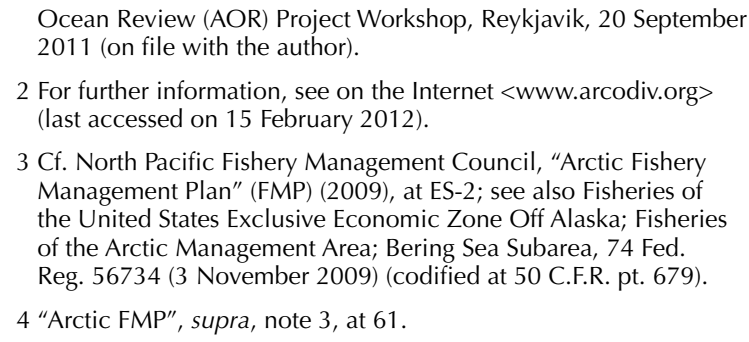


(Section II), examines "Gaps in International Fisheries Fora and Instruments" (Section III), and explores "Potential Options to Address Some Identified Gaps" (Section IV). In order to avoid overlap and to ensure conciseness, reference is made to earlier literature and factual information on Arctic fisheries. ${ }^{5}$

There are no generally accepted geographical definitions for the terms "Arctic" and "Arctic Ocean." For purposes of this article, the term "Arctic" has the same meaning as the term "AMAP area" adopted by the Arctic Monitoring and Assessment Programme (AMAP) of the Arctic Council, ${ }^{6}$ and the waters within the AMAP area are referred to as the "marine Arctic." The term "Arctic Ocean" is defined herein as the marine waters north of the Bering Strait, Greenland, Svalbard, and Franz Josef Land, excluding the Barents Sea. Canada, Denmark/Greenland, Norway, the Russian Federation, and the United States are Arctic Ocean coastal states. There are four high seas pockets in the marine Arctic, namely the so-called "Banana Hole" in the Norwegian Sea, the "Loophole" in the Barents Sea, the "Donut Hole" in the central Bering Sea, and the "Central Arctic Ocean."

Because this article focuses exclusively on marine capture fisheries, it does not address aquaculture. Target species are limited to "fishery resources," which are defined as fish, molluscs, crustaceans and (other) sedentary species, ${ }^{8}$ thus excluding marine mammals.

\footnotetext{
5 See, e.g., David A. Balton, "Considering Future Arctic Fisheries", in Myron H. Nordquist, John N. Moore, and Tomas H. Heidar (eds), Changes in the Arctic Environment and the Law of the Sea (Leiden: Martinus Nijhoff Publishers, 2010), at 401-407; Lori Ridgeway, "Issues in Arctic Fisheries Governance: A Canadian Perspective", in Myron H. Nordquist, John N. Moore, and Tomas $\mathrm{H}$. Heidar (eds), Changes in the Arctic Environment and the Law of the Sea (Leiden: Martinus Nijhoff Publishers, 2010), at 409-446; Erik J. Molenaar, "Arctic Fisheries Conservation and Management: Initial Steps of Reform of the International Legal Framework", 1 Yearbook of Polar Law (2009), at 427-463; Erik J. Molenaar, "Perspective: Law and Policy Dimensions", Proceedings of the International Arctic Fisheries Symposium. Managing Resources for a Changing Arctic (2010), at 23-32. For further information, see "Scientific Report of the 2004 Arctic Climate Impact Assessment" (ACIA), at Chs. 12-13 (available on the Internet at <www.amap.no/acia>, last accessed on 15 February 2012); "Phase I Report" (2009-2011) of the Arctic Ocean Review (AOR) Project, at 30-31 (available on the Internet at <www.pame.is $>$ last accessed on 15 February 2012); Dirk Zeller et al., "Arctic Fisheries Catches in Russia, USA, and Canada: Baselines for Neglected Ecosystems", 34 Polar Biology (2011), at 955-973; and information on Arctic fishing via the Arctic Portal at <arcticportal. org/fishing-portlet $>$ (last accessed on 15 February 2012).
}

6 A map of the AMAP area is available at <www.amap.no $>$ (last accessed on 15 February 2012).

7 Interestingly, the Loophole recently expanded in size due to the entry into force of the 2010 Murmansk Treaty. "Treaty Between

\section{Relevant International Fora and Instruments}

\section{Global Fora and Instruments}

All rules of global international law apply in principle to the marine Arctic, however it is defined. The global component of international fisheries law and bodies therefore apply to the marine Arctic as well. This comprises, inter alia, the Law of the Sea (LOS) Convention, ${ }^{9}$ the Fish Stocks Agreement, ${ }^{10}$ all legally binding and non-legally binding global instruments adopted within the United Nations Food and Agriculture Organization (FAO), nonbinding resolutions of the United Nations General Assembly (UNGA), and the relevant international bodies that adopted these instruments, namely the UNGA and FAO. Key features of the LOS Convention's jurisdictional framework include the sovereignty, sovereign rights, and associated jurisdiction of coastal states over marine capture fisheries within their maritime zones, particularly EEZs and other 200 nautical miles zones, and the right for all states to engage in fishing on the high seas.

The actual applicability of global treaty rules in the marine Arctic nevertheless depends on their being binding on states in various capacities, for instance as coastal states, flag states, or port states. One of the Arctic Ocean coastal states is not party to the LOS Convention, namely the United States, and

the Kingdom of Norway and the Russian Federation Concerning Maritime Delimitation and Cooperation in the Barents Sea and the Arctic Ocean", Murmansk, 15 September 2010, in force 7 July 2011, United Nations Treaty Series (2011), 49095; see English text attached to Press Release No. 118/10, 15 September 2010. See also Erik J. Molenaar, "Fisheries Regulation in the Maritime Zones of Svalbard", 27 International Journal of Marine and Coastal Law (2012), 3, at 9

8 See Convention on Future Multilateral Cooperation in the North-East Atlantic Fisheries, London, 18 November 1980, in force 17 March 1982, 1285 United Nations Treaty Series 129, at Art. 1(b); see also 2004 Amendments, London, 12 November 2004, at Art. 18bis (not in force but provisionally applied by means of the London Declaration of 18 November 2005); 2006 Amendments, London, 11 August 2006, at pmbl, Arts. 1, 2, 4 (not in force but provisionally applied by means of the London Declaration of 18 November 2005).

9 United Nations Convention on the Law of the Sea, Montego Bay, 10 December 1982, in force 16 November 1994, 1833 United Nations Treaty Series (1998), 396.

10 "Agreement for the Implementation of the Provisions of the United Nations Convention on the Law of the Sea of 10 December 1982 Relating to the Conservation and Management of Straddling Fish Stocks and Highly Migratory Fish Stocks", New York, 4 August 1995, in force 11 December 2001, 2167 United Nations Treaty Series (2001), 3. 
some important flag states like China are not party to the Fish Stocks Agreement. ${ }^{11}$ Key global treaty rules are nevertheless also part of customary international law and as such, are binding on all states except those that persistently objected to them. The rights for all states to establish an EEZ and to fish on the high seas are also widely regarded as customary international law. The United States even takes the view that, except for Part XI, the LOS Convention is already part of customary international law such that it creates rights and obligations for the United States. ${ }^{12}$

International fisheries law is not limited to the conservation and sustainable utilization of target species, but also contains obligations regarding nontarget species and the broader marine ecosystem as part of the universally supported - if not universally defined and operationalized - ecosystembased fisheries management. Moreover, beyond the domain of international fisheries law, a large number of global instruments and bodies pursue the conservation of species, habitats, or biodiversity as such, and impose obligations on their parties and members that have the effect of further restraining the exercise of their rights to engage in marine capture fisheries.

Both the LOS Convention and Fish Stocks Agreement are in many ways framework conventions and do not contain key substantive standards of actual fisheries regulation such as the total allowable catch (TAC), its allocation, or restrictions to avoid by-catch of non-target species like dolphins, sea-turtles, or birds. Actual fisheries regulation is carried out by states individually or jointly, including through regional fisheries management organi-

\footnotetext{
11 Information obtained on the Internet from $<$ www.un.org/Depts/los> (last accessed on 9 January 2012).

12 Ronald Reagan, Presidential Proclamation 5030 of 10 March 1983, 48 Fed. Reg. 10605 (14 March 1983) (codified at 3 C.F.R. $\S 1983$ Comp. 22).

13 For purposes of this article, RFMOs also comprise Arrangements as defined infra, Subsection III.5.

14 See U.N. General Assembly, Official Records, UN Doc. A/64/PV.56 (2009), at 3-4.

15 OP 104bis; based on information provided by an official of the European Commission to the author by email on 20 January 2010. See also U.N. General Assembly, Official Records, UN Doc. A/64/PV.56 (2009), at 4.

16 See "Non Papier" de la Délégation Française: Positions Proposées pour le Premier Tour de Négociations sur la Résolution "Pêches" AGNU 2010 (internal document).

17 Report of the $2985^{\text {th }}$ Foreign Affairs Council Meeting, Brussels, 8 December 2009, at 3, para. 10.
}

zations (RFMOs). ${ }^{13}$ The constitutive instruments of RFMOs are stand-alone instruments that are not attached to either the LOS Convention or the Fish Stocks Agreement, e.g., in the form of an implementing agreement or protocol. However, neither the LOS Convention nor the Fish Stocks Agreement stipulate, envisage, or prohibit such an institutional relationship with RFMOs. While an implementing agreement or protocol is therefore possible, the regional instrument would need to be negotiated under the UNGA. This would be unprecedented and extremely unlikely to be acceptable not only to regional coastal states, but also to key flag states because participation in such negotiations would be open to all U.N. Members and would presumably be conducted pursuant to standard U.N. rules of procedure or rules of procedure agreed ad hoc among participants. Regional coastal states and key flag states would thus lose the principal role and influence they commonly have in negotiations to establish RFMOs.

This does not mean that issues relating to Arctic Ocean fisheries are entirely outside the mandate of the UNGA, the annual Informal Consultations of States Parties to the Fish Stocks Agreement (ICSPs), or the ongoing Review Conference of the Fish Stocks Agreement (FSA Review Conference). For instance, in case of actions or inactions of all or certain groups or categories of states are actually or potentially inconsistent with applicable obligations under international fisheries law. This may have been the basis for various EU proposals for the 2009 UNGA Oceans and Sustainable Fisheries Resolutions. ${ }^{14}$ One such proposal concerned an operative paragraph in the 2009 Sustainable Fisheries Resolution, the final version of which

"[called] upon States to conduct further research on fish resources and ecosystems in the high seas, in the context of climate change, including in the Arctic Ocean, and to consider the need to establish appropriate regulatory framework[s] in advance of establishing new fisheries or expanding current fisheries in areas affected by climate change." $15^{2}$

This text contains several elements of a French "non-paper", but not its more far-reaching proposal for a moratorium on new fisheries until regulations are in place. ${ }^{16}$ It should be pointed out, however, that the latter proposal was also incorporated in the EU's 2009 Council Conclusions on Arctic Issues ${ }^{17}$ 
and has similarities with the United States' approach to its EEZ off the coast of Alaska in the Arctic Ocean. ${ }^{18}$

Most of the Arctic Ocean coastal states - except probably the United States in view of its own action on Arctic fisheries - strongly opposed the EU's proposals on a number of grounds, one of which was the inappropriateness of singling out a particular region. It is submitted, however, that references to a particular region are not precluded as such, and that earlier Sustainable Fisheries Resolutions had also singled out particular regions in various ways and for various purposes. ${ }^{19}$ During the plenary debates on the 2009 Oceans and Sustainable Fisheries Resolutions, Norway stated that climate change may lead to "new opportunities to exploit previously inaccessible resources", which would require "orderly and sustainable use", and that the five Arctic Ocean coastal states "have a special responsibility in that regard." ${ }^{20}$ No mention was made of a role for other states or the UNGA. ${ }^{21}$ In the end, only the 2009 Oceans Resolution included a general preambular paragraph with no mention of fisheries issues. ${ }^{22}$ This result and the Norwegian statement indicate that, apart from the United States, Arctic Ocean coastal states took the view that the UNGA played no role in Arctic fisheries, certainly not in developing regulations under its auspices, but also not even in raising the issue of their establishment per se. While the EU may initially have considered raising the issue of Arctic fisheries in the UNGA again, official records of the plenary debates on the 2010 and 2011 Oceans and Sustainable Fisheries Resolutions do not indicate any discussion to that effect. The 2009 preambular paragraph was nevertheless retained in the 2010 and 2011 Oceans Resolutions. ${ }^{23}$

18 See supra, note 3 and accompanying text.

19 See, e.g., "2008 Sustainable Fisheries Resolution No. 63/112", UN Doc. A/RES/63/112, 24 February 2009, at paras. 83-84, 86-87, 105, 115.

20 U.N. General Assembly, Official Records, Doc. No. A/64/PV.56 (2009), at 16. See also Chair's Summary of the Arctic Ocean Coastal States Meeting ("Arctic Ocean coastal states have a unique interest and role to play in current and future efforts for the conservation and management of fish stocks in this region"), available on the Internet at $<w w w$.international.gc.ca/polarpolaire/arctic-meeting_reunion-arctique-2010_index> (last accessed on 12 January 2012).

21 It is assumed that the official records are correct on this point, as such an omission would have been crucial and highly likely to have been rectified by Norway.

22 The paragraph reads "Reiterating its deep concern at the vulnerability of the environment and the fragile ecosystems of the polar
A role for the FAO is highly unlikely as well. Since 1993 when the India Ocean Tuna Commission (IOTC) Agreement ${ }^{24}$ was adopted, no constitutive instrument for an RFMO with a (partial) high seas mandate has been adopted under the FAO. Several parties to the IOTC Agreement currently prefer bringing it in one way or another outside the framework of the FAO in order to facilitate the participation of Taiwan (Chinese Taipei). ${ }^{25}$ Arctic Ocean coastal states are also unlikely to be interested in the various types of assistance that FAO could offer to bodies established within its framework and their members. Finally, neither Arctic Ocean coastal states nor key high seas fishing states and entities would be supportive of negotiations under the FAO for reasons similar to those mentioned above in relation to negotiations under the auspices of the UNGA.

\section{Regional and Bilateral Fora and Instruments}

\section{a. Introduction}

The marine Arctic is covered by a considerable number of regional and bilateral fisheries instruments and bodies. As fairly comprehensive overviews of these already exist, ${ }^{26}$ the following discussion will focus on the Arctic Ocean as defined above in Section I.

A distinction between the Arctic Ocean and the more southerly waters of the marine Arctic is useful for a number of reasons. First, compared to the more southerly waters, there are considerable shortcomings in the data, knowledge, and insight required for science-based and ecosystem-based fisheries

regions, including the Arctic Ocean and the Arctic ice cap, particularly affected by the projected adverse effects of climate change." U.N. General Assembly Resolution No. 64/71, "Oceans and the Law of the Sea", UN Doc. A/RES/64/71, 12 March 2010, at 3 .

23 U.N. General Assembly Resolution No. 65/37, "Oceans and the Law of the Sea", UN Doc. A/RES/65/37, 17 March 2011, at 3; Draft U.N. General Assembly Resolution, "Oceans and the Law of the Sea", UN Doc. A/66/L.21, 28 November 2011, at 3 .

24 Agreement for the Establishment of the Indian Ocean Tuna Commission, Rome, 25 November 1993, in force 27 March 1996.

25 See, e.g., "Report of the 2011 IOTC Meeting", at 35, 105.

26 For an overview, see Molenaar, "Arctic Fisheries Conservation and Management", supra, note 5; "AOR Project Phase I Report" (2009-2011), supra, note 5. 
management in the Arctic Ocean. Second, while there are large-scale commercial fisheries in the more southerly waters, there are currently mainly small-scale subsistence fisheries and no significant commercial fisheries in the Arctic Ocean, and no fisheries at all in the Central Arctic Ocean. Third, while the more southerly areas are adequately covered by regional and bilateral fisheries instruments and bodies, the ensuing discussion will show that there are gaps in the coverage of the Arctic Ocean.

The ensuing subsections focus on the North-East Atlantic Fisheries Commission (NEAFC) and the Joint Commission and other regional and bilateral fora and instruments. No separate subsection is devoted to anadromous fish or tuna and tuna-like species. However, whereas significant occurrence of tuna and tuna-like species in the Arctic Ocean is not expected in the short or medium term, this may well be different for anadromous species.

Finally, some observations are offered regarding the Spitsbergen Treaty ${ }^{27}$ and its application to the maritime zones of Svalbard. Due to the fundamental disagreement on the spatial scope of the Spitsbergen Treaty that exists between Norway and most other parties to the Treaty, Norway has established a Fisheries Protection Zone (FPZ) around Svalbard rather than an EEZ. Several states enjoy fisheries access to the FPZ and territorial waters of Svalbard

27 "Treaty concerning the Archipelago of Spitsbergen", Paris, 9 February 1920, in force 14 August 1925, 2 League of Nations Treaty Series (1920), 7.

28 For further discussion see Molenaar, "Fisheries Regulation in the Maritime Zones of Svalbard", supra, note 7.

29 See supra, note 8 .

30 "Agreement between the Government of the Kingdom of Norway and the Government of the Union of Soviet Socialist Republics on Co-operation in the Fishing Industry", Moscow, 11 April 1975, in force 11 April 1975, 983 United Nations Treaty Series (1975), 7.

31 Information provided by Stefán Ásmundsson, NEAFC Secretary, to the author on 23 December 2011.

32 North-East Atlantic Fisheries Commission, Scheme of Control and Enforcement (2010), at Art. 1(a).

33 The segment is defined as "the waters of the Convention Area, which lie beyond the waters under the fisheries jurisdiction of Contracting Parties." NEAFC Scheme of Control and Enforcement, as amended at the $29^{\text {th }}$ Annual NEAFC Meeting (2010), in effect 5 February 2011, at Art. 1(b).

34 See supra, note 33.

35 See "Regulations of Bottom Fishing Activities in the NEAFC Regulatory Area", available via the NEAFC website at <http://neafc.org/system/files/consolidated_bottomfishing regulations.pdf> (last accessed on 15 February 2012), which consolidates all relevant NEAFC recommendations.

36 See supra, note 7. as a result of the provisions of equal access laid down in the Spitsbergen Treaty. ${ }^{28}$ It is also worth pointing out that Norway is an Arctic Ocean coastal state exclusively on account of Svalbard and not also on account of mainland Norway.

\section{b. NEAFC and the Joint Commission}

The two bodies whose competence extends explicitly or implicitly over part of the Arctic Ocean are the North-East Atlantic Fisheries Commission (NEAFC) established by the NEAFC Convention, ${ }^{29}$ and the Joint Norwegian-Russian Fisheries Commission (Joint Commission) established by the bilateral 1975 Framework Agreement. ${ }^{30}$ NEAFC currently has five members and three cooperating non-contracting parties (NCPs). The current members are Denmark (in respect of the Faroe Islands and Greenland), the European Union (EU), Iceland, Norway, and the Russian Federation; Canada, New Zealand, and Saint Kitts and Nevis were granted cooperating NCP status for 2012. ${ }^{31}$ The NEAFC Convention Area includes a segment of the (Central) Arctic Ocean. ${ }^{32}$ While most of the species-specific NEAFC recommendations apply within the entire NEAFC Regulatory Area $^{33}$ and occasionally also within the entire NEAFC Convention Area, none of the species involved currently occur in the Arctic Ocean in commercially significant quantities. More concretely relevant are several non-species-specific recommendations and the NEAFC Scheme ${ }^{34}$ that apply to the Arctic Ocean segment of the Regulatory Area or the Convention Area. While the recommendations on bottom fisheries ${ }^{35}$ appear especially relevant at first sight, there may not be significant quantities of bottom species due to the considerable depth of the Arctic Ocean segment of the NEAFC Regulatory Area.

As the spatial mandate of the Joint Commission is not explicitly defined in the 1975 Framework Agreement, it is not exclusively confined to the maritime zones of the two states, the high seas, or the Barents Sea. Fisheries for species whose distributional range extends into the (Central) Arctic Ocean therefore fall, in principle, within the Joint Commission's mandate. The Joint Commission's competence over the Arctic Ocean has been asserted on several occasions. First, the full title of the 2010 Murmansk Treaty $^{36}$ confirms that bilateral cooperation also relates to the Arctic Ocean. Second, the Joint Commission decided at its 2009 meeting to submit a request to the International Council for 
the Exploration of the Sea (ICES) on the monitoring of the distribution in the Arctic Ocean of the stocks managed by the Joint Commission. ${ }^{37}$ ICES responded in June 2011 by noting that it "is possible to monitor the geographic distribution of these stocks in the ice-free parts of the Arctic Ocean once a year, using existing survey methodology. This could be coordinated by existing ICES expert groups." ${ }^{38}$ At its 2011 meeting, the Joint Commission did not take further steps on this matter.

A unique feature of the Joint Commission is that Norway and the Russian Federation have encouraged third party states and entities to discontinue or not commence fishing for particular species in the Loophole, and thereby not exercise their entitlements under international law to fish in the high seas and participate in high seas fisheries management. ${ }^{39}$ In return, the two states have granted fisheries access to their maritime zones and discontinued withholding benefits such as access to ports. The trilateral Loophole Agreement between Iceland, Norway, and the Russian Federation ${ }^{40}$ is a result of this approach.

The Joint Commission's competence over the Arctic Ocean relates first of all to areas adjacent to the Barents Sea that are part of the maritime zones of Norway and the Russian Federation. While its constitutive instrument would also allow the Joint Commission to exercise competence over the Central Arctic Ocean, this would be problematic as Canada, Denmark/Greenland, and the United States are also coastal states to the Central Arctic Ocean, and other third party states and entities, including members of NEAFC, are unlikely to accept the Joint Comission to exercise competence over the Central Arctic Ocean if this would occur in ways similar to the Loophole. ${ }^{41}$ Another potentially complicating factor is that Norway is an Arctic Ocean coastal state exclusively on account of Svalbard. The dispute on the spatial scope of the Spitsbergen Treaty as discussed above might therefore become involved.

\section{c. Other Regional and Bilateral Fora and Instruments}

Not to be overlooked are the meetings of the Arctic Ocean coastal states; two ministerial meetings have taken place so far. The first, in May 2008, was held in Ilulissat, Greenland, and culminated in the famous Ilulissat Declaration, ${ }^{42}$ and the second in March 2010, was held in Chelsea, Canada. ${ }^{43}$ These high-level meetings have been criticized by the Arctic Council's three other members - Finland, Iceland and Sweden - as well as its Permanent Participants on the ground that it undermines the functioning of the Council. ${ }^{44}$ Arctic Ocean fisheries were specifically discussed at the 2010 meeting but did not result in concrete output. ${ }^{45}$ The Arctic Ocean coastal states also held several dedicated fisheries meetings among senior officials, the last held June 2010, in Oslo, Norway. ${ }^{46}$ The participants recognized shortcomings in the available scientific information and agreed to organize a meeting of scientific experts, ${ }^{47}$ which took place in June 2011 , in Anchorage, Alaska. No information on this meeting is publicly available.

With respect to bilateral cooperation other than the aforementioned agreement between Norway and the Russian Federation, reference can be made to cooperation between Greenland and Norway pursuant to the 1992 Agreement on Mutual Fishery Relations, ${ }^{48}$ which is, inter alia, implemented through

37 Cf. Protocol of the 2009 Meeting of the Joint Commission, para. 14.1, available on the Internet at $<w w w . j o i n t f i s h . n o>$ (last accessed on 12 January 2012).

38 Special Request Advice, Monitoring of Arctic Ocean Fish Stocks, June 2011 (on file with author).

39 These entitlements are set forth in Art. 116 of the LOS Convention and Art. 8(3) of the Fish Stocks Agreement.

40 "Agreement between the Government of Iceland, the Government of Norway and the Government of the Russian Federation Concerning Certain Aspects of Co-operation in the Area of Fisheries", St. Petersburg, 15 May 1999, in force 15 July 1999, 41 Law of the Sea Bulletin (1999), 53. This Agreement is complemented by two protocols between Iceland and Norway, and Iceland and the Russian Federation, respectively, which are currently in force. See Molenaar, "Fisheries Regulation in the Maritime Zones of Svalbard", supra, note 7, at 35 .

41 Cf. Erik Molenaar, "Perspective: Law and Policy Dimensions", in Proceedings of the International Arctic Fisheries Symposium [IAFS]: Managing Resources for a Changing Arctic, 19-21 October 2009 (2010), at 26.

42 Ilulissat Declaration, Arctic Ocean Conference, 28 May 2008; available on the Internet at $<w w w$.arctic-council.org $>$ (last accessed on 12 January 2012).

43 See Chair's Summary, supra, note 20.

44 See, e.g., Meeting of Senior Arctic Officials, Final Report, 28-29 April 2010, at 20.

45 See Chair's Summary, supra, note 20.

46 See Chair's summary, available on the Internet at $<$ www.regjeringen.no/upload/UD/Vedlegg/Folkerett/chair_ summary100622.pdf> (last accessed on 15 February 2012).

47 Ibid.

48 "Agreement between Greenland/Denmark and Norway Concerning Mutual Fishery Relations", Copenhagen, 9 June 1992, in force 4 March 1994 (provisionally in force with retroactive effect from 24 September 1991), 1829 United Nations Treaty Series (1994), 223. 
annual consultations. Bilateral cooperation between Greenland and the Russian Federation occurs pursuant to a 1992 Agreement on Mutual Fishery Relations, ${ }^{49}$ presumably also implemented through annual bilateral consultations. The scope of these two instruments does not exclude the Arctic Ocean and extends beyond areas of national jurisdiction. ${ }^{50}$

Bilateral cooperation between Canada and Greenland is not formalized, even though meetings are held on an annual basis. While these used to be exclusively related to shared stocks in Baffin Bay and Davis Strait, ${ }^{51}$ recent meetings had a much broader focus and in principle encompassed all bilateral and regional fisheries, marine mammals, and other pertinent issues. ${ }^{52}$ In addition, joint fisheries research is undertaken pursuant to a Memorandum of Understanding (MOU) on scientific collaboration between the Canadian Department of Fisheries and Oceans and the Greenland Institute of Natural Resources. ${ }^{53}$

Bilateral cooperation between the Russian Federation and the United States takes place, inter alia, within the bilateral Intergovernmental Consultative Committee (ICC) established by a 1988 Agreement on Mutual Fisheries Relations. ${ }^{54}$ As its mandate is not geographically delimited, the ICC has provided a forum to discuss a wide range of fisheries issues. Discussions have also related to Arctic Ocean fisheries, including most recently at the 2011 ICC Meeting. Ongoing negotiations on a comprehensive fisheries agreement for the Northern Bering Sea within the ICC made no real progress in recent years; in any event, the envisaged agreement will not apply to fisheries north of the Bering Strait. ${ }^{55}$

In addition to this more formalized bilateral $\mathrm{co}^{-}$ operation, informal bilateral and/or trilateral meet-

49 "Agreement Between the Government of the Kingdom of Denmark and the Local Government of Greenland, on the One Hand, and the Government of the Russian Federation, on the Other Hand, Concerning Mutual Fishery Relations Between Greenland and the Russian Federation", Copenhagen, 7 March 1992, in force 16 October 1992 (provisionally 7 March 1992), 1719 United Nations Treaty Series (1993), 89.

50 See "1992 Agreement", supra, note 48, at Art. 6(b); "1992 Agreement", supra, note 49, at Art. 7.

51 Cf. Ridgeway "Issues", supra, note 5, at 417.

52 Information provided by I. Holm Olsen by email to the author on 23 February 2012.

53 Information obtained on the Internet at <www. international. gc.ca/polar-polaire> (last accessed on 12 January 2012).

54 "Agreement Between the Government of the United States of America and the Government of the Union of Soviet Socialist ings occur among Arctic Ocean coastal states, and perhaps also with the participation of certain third party states and the EU. The United States is particularly active in this regard due to its Senate Joint Resolution No. 17 of 2007, which "direct[s] the United States to initiate international discussions and take necessary steps with other Nations to negotiate an agreement for managing migratory and transboundary fish stocks in the Arctic Ocean." 56

\section{The Arctic Council and Arctic Council System}

The Arctic Council is a high-level forum established by the Ottawa Declaration. ${ }^{57}$ The choice of a nonlegally binding instrument is a clear indication that the Council was not intended to be an international organization and implies that it cannot adopt legally binding decisions or instruments. The Arctic Search and Rescue (SAR) Agreement ${ }^{58}$ was negotiated under the Council's auspices but not adopted by it, even though the Council's Ministerial Meeting in May 2011 was used as the occasion for its signature.

Thus far, the Arctic Council has not explicitly involved itself in fisheries management issues, neither as the Arctic Council nor through the Arctic Council System (ACS); see further below. Nevertheless, there is no juridical obstacle to either. The Arctic Council's mandate broadly relates to "common Arctic issues" with special reference to "issues of sustainable development and environmental protection in the Arctic." ${ }^{59}$ A footnote specifies, however, that the Council "should not deal with matters related to military security."

Republics on Mutual Fisheries Relations", Moscow, 31 May 1988, in force 28 October 1988, Treaties and Other International Acts Series (1988), 11442.

55 Information provided by a United States government official to the author by email on 10 January 2012.

56 The Senate passed Joint Res. No. 17 on 4 October 2007, the House of Representatives approved it in May 2008, and President Bush signed it on 4 June 2008.

57 "Declaration on the Establishment of the Arctic Council", Ottawa, 19 September 1996, available on the Internet at $<$ www.arctic-council.org > (last accessed on 12 January 2012).

58 "Agreement on Cooperation in Aeronautical and Maritime Search and Rescue in the Arctic", Nuuk, 12 May 2011 (not in force), available on the Internet at $<w w w$.arctic-council.org $>$ (last accessed on 12 January 2012).

59 "Ottawa Declaration", supra, note 57, at Art. 1. 
In spite of this very broad mandate, the Council has avoided involvement in certain marine mammal issues. ${ }^{60}$ Moreover, at the November 2007 Meeting of the Senior Arctic Officials (SAOs), the Arctic Council decided not to become involved in fisheries management issues. The matter arose after the United States brought Joint Resolution No. $17^{61}$ to the SAOs' attention. The ensuing discussion was summarized as follows: "There was strong support for building on and considering this issue within the context of existing mechanisms." 62

Even though the Council has not explicitly reversed its view since then, the issue of international fisheries management has come up within the context of the Arctic Ocean Review (AOR) project that is currently carried out within the Council's Protection of the Arctic Marine Environment (PAME) working group. Completion of Phase I of the AOR project was marked by the submission of the Phase I Report (2009-2011) to the 2011 Nuuk Ministerial Meeting. ${ }^{63}$ The report's primary objective is essentially to provide a factual overview of the status of Arctic marine ecosystems, relevant global and regional fora and instruments - including on fisheries - and integrated oceans management. Phase II has a very different objective as it is intended to culminate in a final report that will

"summarize potential weaknesses and/or impediments in the global and regional instruments and measures for [the] management of the Arctic marine environment; outline options to address these weaknesses and/or impediments; and, make agreed recommendations to help ensure a healthy and productive Arctic marine environment in light of current and emerging trends." ${ }^{64}$

To this end, a first round of discussions took place in September $2011 .{ }^{65}$ If the Council decides to pursue one or more of the options outlined in the AOR Final Report, it could do so within the Council, for instance through an assessment complemented by policy-recommendations ${ }^{66}$ or non-legally binding guidelines. $^{67}$

As mentioned above, the Council could also pursue certain options through the ACS. The Concept of the ACS - introduced and explained in more detail elsewhere ${ }^{68}$ - consists of two categories. In the first category are the Ottawa Declaration and other ministerial declarations and instruments adopted by the Arctic Council - for instance its Arctic Offshore Oil and Gas Guidelines ${ }^{69}$ - and the
Council's institutional component. The second category consists of instruments negotiated, but not adopted, under the Council's auspices and the institutional component established by them. Examples include the Arctic SAR Agreement and Meetings of the Parties envisaged under Article 10 of the Agreement. Expansion of this category is envisaged due to ongoing negotiations for an Arctic instrument on marine oil pollution preparedness and response, which may be finalized at the Arctic Council's 2013 Ministerial Meeting in Kiruna, Sweden. ${ }^{70}$

\section{Gaps in International Fisheries Fora and Instruments Relating to the Arctic Ocean}

\section{Introduction}

The subsections below identify four main gaps in the existing regime of international fisheries fora and instruments relating to the Arctic Ocean, namely lack of data, inadequate domestic regulation, gaps in Arctic Ocean coastal state fora and instruments and gaps in high seas coverage with RFMOs or Arrangements. The first two subsections also include some information on actions that have already been undertaken to address the first two gaps. With respect to the last two, potential options to address them are discussed in more detail in Sec-

60 Cf. Evan T. Bloom, "Establishment of the Arctic Council", 93 American Journal of International Law (1999), at 712, 720.

61 See supra, note 56.

62 Cf. Meeting of Senior Arctic Officials, Final Report, 28-29 November 2007, at 12.

63 See supra, note 5.

64 "Phase I Report (2009-2011)", supra, note 5, at 3.

65 See "Report from the AOR Expert Workshop in Support of the AOR Phase II Report", Reykjavík, Iceland, 20-21 September 2011 (on file with author).

66 E.g., Modeled on the Arctic Marine Shipping Assessment (AMSA).

67 E.g. The Council's Arctic Offshore Oil and Gas Guidelines (last updated in 2009, available on the Internet at <www.pame.is $>$ ).

68 Erik J. Molenaar, "Current and Prospective Roles of the Arctic Council System within the Context of the Law of the Sea", in T. Axworthy, T. Koivurova and W. Hasanat (eds) The Arctic Council: its Place in the Future of Arctic Governance (<gordonfoundation. $\mathrm{ca} /$ node/530>), pp. 139-189; also published in 27 International Journal of Marine and Coastal Law (2012: forthcoming)

69 See supra, note 67.

70 Cf. "Nuuk Declaration on the Occasion of the Seventh Ministerial Meeting of the Arctic Council", 12 May 2011, Nuuk, Greenland, at 4. 
tion IV. Finally, the adequacy of the 'nesting' of the existing regime of international fisheries fora and instruments relating to the Arctic Ocean into more holistic ecosystem-based oceans management cannot be discussed in this article.

\section{Lack of Data}

Arctic Ocean coastal states agree that science- and ecosystem-based fisheries management in the Arctic Ocean requires more and better data than is currently available. This information gap has, inter alia, been addressed through a joint request made to ICES by Norway and the Russian Federation (see infra, Subsection II.2) and recent cooperative activities between ICES and the North Pacific Marine Science Organization (PICES). ${ }^{71}$ Future options include a one-off assessment on Arctic fisheries within or outside the Arctic Council, or the establishment of a new permanent scientific assessment and advisory body on Arctic fisheries. Such an advisory body could be self-standing, set up within the Arctic Council, ${ }^{72}$ ICES, or the International Arctic Science Committee (IASC), or established jointly by ICES/ PICES. If states chose to conduct an assessment, it should as a minimum include plausible future scenarios ${ }^{73}$ and take account of the impacts of fisheries intensification and expansion on Arctic indigenous peoples.

\section{Inadequate Domestic Regulation}

Not all relevant actors - Arctic Ocean coastal states as well as other states and entities - are likely to

71 In 2009, ICES and PICES formed their first joint working group, the Working Group on Forecasting Climate Change Impacts on Fish and Fisheries (WGFCCIFS), and convened the "PICES/ICES Workshop on Biological Consequences of a Decrease in Sea Ice in Arctic and Sub-Arctic Seas" in May 2011. The Report of this Workshop is available via the ICES website on the Internet at $<$ www.ices.dk> under Doc. ICES CM 2011/SSGHIE:14 (last accessed on 15 February 2012)

72 Note that the Report of the 2011 AOR Phase II Expert Workshop identified the establishment of an Arctic Council working group on "Arctic Oil and Gas." See supra, note 65, at 5, 7.

73 The PICES/ICES WKBCASAS REPORT 2011, supra, note 71 , can be considered to be a first step in this regard.

74 U.N. Food and Agriculture Organization, Committee on Fisheries, International Plan of Action to Prevent, Deter and Eliminate Illegal, Unreported and Unregulated Fishing (IPOA-IUU), adopted by consensus 2 March 2001 (endorsed by the FAO Council 23 June 2001), at para. 3.3.2.

75 See supra, note 3, and accompanying text. have adequate laws and regulations in place. Specifically, states should ensure that new Arctic Ocean fisheries in their own maritime zones and/or by their vessels comply with the applicable global and regional fisheries standards, or, where these do not exist, that activities are not conducted in such an unregulated manner that this would be "inconsistent with State responsibilities for the conservation of living marine resources under international law."74

The United States' action with respect to its EEZ off Alaska in the Arctic Ocean ${ }^{75}$ clearly precludes this because United States law prohibits commercial fishing in that area. Norway's laws and regulations relating to fisheries in Svalbard's maritime zones, however, allow "unregulated fisheries" - but not necessarily in the sense discussed above - to continue or develop, unless explicitly prohibited. ${ }^{76}$ Canada's 2001 New Emerging Fisheries Policy ${ }^{77}$ differs from both approaches as it neither freezes expansion nor allows unregulated fisheries to develop, but requires licenses for each of its three stages, i.e., feasibility, exploratory, and commercial stages. ${ }^{78}$ Other Canadian policies would apply to new Arctic fisheries as well. $^{79}$

The approaches taken by Canada and the United States are both precautionary and pro-active, although in different ways. The legal and policy frameworks of most Arctic Ocean coastal states and other key states and entities probably adopt the precautionary approach, even though not necessarily directly in relation to (new) Arctic fisheries. The Kingdom of Denmark's "Strategy for the Arctic" acknowledges that illegal, unreported, and unregulated fishing is a serious threat; that the lack of

\footnotetext{
76 Cf. Molenaar, "Fisheries Regulation in the Maritime Zones of Svalbard", supra, note 7 , at 50 .

77 The Emerging Fisheries Policy is one of Canada's Fisheries Management Policies and is available on the Internet at $<$ www.dfo-mpo.gc.ca $>$ (last accessed on 2 February 2012).

78 See Ridgeway, "Issues in Arctic Fisheries Governance", supra, note 5, at 431-433. Note also the May 2010 Report of Canada's Standing Senate Committee on Fisheries and Oceans on "The Management of Fisheries and Oceans in Canada's Western

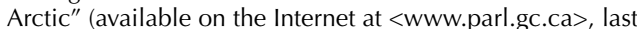
accessed on 15 February 2012) recommends that Canada adopt an approach for the Canadian part of the Beaufort Sea similar to the United States' Arctic FMP (Recommendation No. 12).

79 Particularly relevant seem to be the "Policy for Managing the Impacts of Fishing on Sensitive Benthic Areas" and the "Policy on New Fisheries for Forage Species", both available on the Internet at <www.dfo-mpo.gc.ca > (last accessed on 28 February 2012).

80 Denmark, Greenland and the Faroe Islands, "Kingdom of Denmark Strategy for the Arctic 2011-2020" (2011).
} 
knowledge of fish stocks and fishing opportunities calls for the application of the precautionary approach; and that fisheries should not commence where a conservation and management system is not available, while explicitly mentioning the Central Arctic Ocean. ${ }^{81}$ This position is in many respects similar to that of the EU Council, which also embraces the precautionary approach and implements this through support for a temporary ban on new fisheries. ${ }^{82}$ An earlier position of the European Commission, ${ }^{83}$ later taken by the European Parliament, ${ }^{84}$ also stressed the need to avoid unregulated fishing. Conversely, while Norway's plan, "The High North: Visions and Strategies"85 emphasizes the need for sustainable and sciencebased fisheries management and the application of the precautionary approach in a general sense, it devotes no attention to new fisheries. ${ }^{86}$ It is unclear whether other key high seas fishing states and entities such as China, Iceland, Japan, South Korea, or Taiwan have policies on (new) Arctic fisheries.

These practices and policy statements will function as points of departure in ongoing and prospective international discussions on the international regime for Arctic Ocean fisheries. The contrast between many of these policy statements - even the more explicit ones - and the United States' action with respect to its EEZ off Alaska in the Arctic Ocean is nevertheless obvious. Whereas the United States actually constrains fisheries by its nationals already, most of the policy statements by other states or entities merely advocate or envisage similar action.

The action taken by the United States is also noteworthy in light of the consensual nature of international law. Rather than awaiting agreement at the international level, the United States proactively adopted more stringent domestic regulation unilaterally, thereby essentially creating a competitive disadvantage for itself. As some of the fish stocks that occur in its EEZ off Alaska in the Arctic Ocean may be transboundary, and in view of a more general preference for a level playing field, the United States must have hoped, and continues to do so, that other states and entities would follow with similar regulations or actions with similar effectiveness. ${ }^{87}$ But while some states may appreciate the United States' leadership, others may be annoyed by its failure to allow international consensus to crystallize. In both cases, states and entities must ensure that new Arctic Ocean fisheries are conducted in compliance with applicable international law. When policy statements are inadequate for this purpose, which is often the case, states and entities must implement policy into domestic regulation, acting in all relevant capacities, e.g., as coastal states, flag states, port states, market states, or with regard to their natural or juridical persons.

\section{Gaps in Arctic Ocean Coastal State Fora and Instruments}

As indicated by the discussion above in Subsection II.2, there are several gaps in Arctic Ocean coastal state fora and instruments. For example, the existing bilateral cooperation between Canada and Greenland could be formalized and explicitly relate also to their maritime zones in the Arctic Ocean and the high seas beyond. Gaps also exist in relation to bilateral cooperation between neighboring states, namely between Canada and the United States, and the Russian Federation and the United States. The bilateral cooperation between Greenland and the Russian Federation indicates that cooperation between non-neighboring coastal states may also be necessary and/or desirable.

New fora and instruments could relate to the conservation and management of shared, straddling, or anadromous fish stocks; or could provide a framework for mutual fisheries access and exchange of fishing opportunities. Such fora and instruments could be bilateral, trilateral, or involve all Arctic Ocean coastal states.

\section{Gaps in High Seas Coverage with RFMOs or Arrangements}

The discussion above in Subsection II.2 also highlighted that, apart from the Atlantic sector, the gap in coverage of the Central Arctic Ocean related in

\footnotetext{
81 lbid., at 31-32.

82 See supra, note 17 , and accompanying text.

83 "Communication from the Commission to the European Parliament and the Council on The European Union and the Arctic Region", $\operatorname{COM}(2008)$ 763, of 20 November 2008, at 7-8.

84 European Parliament Resolution of 20 January 2011, "A Sustainable EU Policy for the High North" (2009/2214(INI)); Doc. P7_TA(2011)0024, para. 22.

85 Norway Ministry of Foreign Affairs, "The High North: Visions and Strategies" (2011).

86 See, e.g., ibid., at 13, 28, 40.

87 Cf. IAFS Proceedings, supra, note 41 , at 28
} 
particular to an RFMO with competence over fish stocks other than anadromous fish stocks and highly migratory fish stocks. It should be recalled that, for purposes of this article, the acronym RFMO includes a so-called "Arrangement," which is defined in the Fish Stocks Agreement as

"a cooperative mechanism established in accordance with the [LOS] Convention and this Agreement by two or more States for the purpose, inter alia, of establishing conservation and management measures in a subregion or region for one or more straddling fish stocks or highly migratory fish stocks." 88

This definition is not very restrictive. The main conditions to satisfy are consistency with international law and a purpose that falls within the scope of the Fish Stocks Agreement. This does not prevent states from establishing an Arrangement with a purpose that extends beyond the scope of the Fish Stocks Agreement, for instance because it also deals with discrete high seas fish stocks. Such Arrangements must nevertheless comply with other rules of international law, including the LOS Convention and customary international law. It is this broader meaning of the term Arrangement that is adopted in this article.

The three main differences between an RFMO's constitutive instrument and an Arrangement are that the latter (a) does not establish an international organization, (b) does not have to be legally binding, and (c) can be bilateral. Examples of wellknown Arrangements include the Central Bering Sea (CBS) Convention, ${ }^{89}$ the Southern Indian Oceans Fisheries (SIOF) Agreement, ${ }^{90}$ and the trilateral Loophole Agreement. ${ }^{91}$ The fact that the purpose, structure, and substance of these Arrangements varies considerably implies that the choice for an Arrangement within the context of Arctic
Ocean fisheries leaves participants ample room for tailor-made design.

While a gap in high seas coverage with RFMOs or Arrangements thus undeniably exists for most of the Central Arctic Ocean, this does not automatically mean that relevant states are under an international obligation to ensure full coverage with RFMOs or Arrangements. As regards straddling and highly migratory fish stocks, Article 8(5) of the Fish Stocks Agreement explicitly uses the phrase "a particular straddling fish stock or highly migratory fish stock." While highly migratory fish stocks currently do not occur in the Central Arctic Ocean, this may be different for straddling fish stocks.

This notwithstanding, a new RFMO or Arrangement is openly supported as a potential option by the United States, the EU, ${ }^{92}$ and Denmark (on behalf of the entire Kingdom). ${ }^{93}$ High-level Canadian officials have also expressed support in recent years, even though more so in relation to an Arrangement than an RFMO, and not as a matter that needed to be addressed urgently. ${ }^{94}$

\section{Potential Options to Address Identified Gaps in International Law}

\section{Preliminary Choices}

In the scoping phase of considering potential options, several preliminary choices have to be made. The lead role for consultations or negotiations clearly lies with Arctic Ocean coastal states. This is not only evident for options that relate exclusively to coastal state maritime zones, but the debate on the 2009 UNGA Oceans and Sustainable Fisheries Resolutions (see Subsection II.1) suggests that Arctic Ocean coastal states also claim a lead role on options that include the high seas.
88 "Fish Stocks Agreement", supra, note 10, at Art. 1(1)(d).

89 Convention on the Conservation and Management of Pollock Resources in the Central Bering Sea, Washington, 16 June 1994, in force 8 December 1995, 34 International Legal Materials (1995), 67.

90 Southern Indian Ocean Fisheries Agreement, Rome, 7 July 2006, not in force $<w w w$.fao.org/legal $>$.

91 See supra, note 40.

92 Cf. European Parliament Resolution of 20 January 2011 , supra, note 84 , at para. 22. While the EU's Council Conclusions on Arctic Issues (see supra, note 17, at para. 10) repeats the option of extending the mandate of existing RFMOs - in line with the earlier suggestion in the European Commission's Arctic Communication (see supra, note 83 , at 8 ) - this is followed by the phrase "or any other proposal to that effect agreed by the relevant parties."

93 "Strategy for the Arctic", supra, note 80, at 32.

94 Cf. Ridgeway, "Issues", supra, note 5, at 442; "IAFS Proceedings", supra, note 41 , at 28 (discussing a presentation by David Sproule of Canada). 
Other preliminary choices are addressed through the following questions:

\section{i. Should new instruments or bodies be established or should existing instruments and bodies be built upon? In case of new instruments, should these be legally binding or non-legally binding?}

The first question has already surfaced several times, for instance in relation to the Joint Norwegian-Russian Fisheries Commission, when the European Commission proposed to extend the mandates of existing RFMOs and specifically referred to NEAFC in that regard; ${ }^{95}$ and when the United States triggered a discussion on Arctic fisheries issues in the Arctic Council.

As regards the Joint Commission, subsection II.2(b) concluded that relevant states and entities are unlikely to accept the Joint Commission's competence over the Central Arctic Ocean if this would occur in ways similar to the Loophole. Likewise, an extension of NEAFC's mandate does not seem to be supported by any of the Arctic Ocean coastal states. ${ }^{96}$ Finally, as noted in Subsection II.3, in November 2007 the Arctic Council decided not to become involved in fisheries management issues, even though it could of course reverse this decision in light of the follow-up of the AOR project. As examined further in Subsection IV.2, this could be done within either the Arctic Council as such or the ACS. If this option is not pursued, however, there seem to be no other options for building on existing instruments and bodies that would have sufficient support.

The second question raised above relates to the new instrument's nature under international law; namely being legally binding or non-legally binding. The usual advantages and disadvantages of each of these options apply here as well. In addition, it may be that a legally binding instrument is preferable because it is more likely to be perceived by the international community as a more responsible and committed response.

\footnotetext{
95 Cf. "European Commission's Arctic Communication", supra, note 83 , at 8 .

96 For some reasons, see "IAFS Proceedings", supra, note 41, at 26; Molenaar, "Fisheries Conservation", supra, note 5, at 456-458

97 Compare the different wording in Arts. 63(2) and 64 of the LOS Convention, notably the inclusion of the phrase "within and beyond the exclusive economic zone" in the latter.
}

ii. Excluding the area covered by the NEAFC Convention, should there be separate bodies and/or instruments for coastal state maritime zones and the Central Arctic Ocean, or should there (also) be one single body and/or instrument for the entire Arctic Ocean?

Pursuing separate options for the high seas and coastal state maritime zones for fish stocks other than tuna and tuna-like stocks ${ }^{97}$ would follow normal practice in international fisheries law. In order to secure support from non-Arctic Ocean coastal states and entities for a high seas body and/or instrument, however, there would need to be compatibility between high seas conservation and management measures and those for coastal state maritime zones. ${ }^{98}$

A single body and/or instrument could be designed to address the gap in high seas coverage with RFMOs or Arrangements as well as gaps in Arctic Ocean coastal state fora and instruments, without prejudice, of course, to existing Arctic Ocean coastal state fora and instruments. Such a single body and/ or instrument could be a suitable vehicle for addressing the issue of compatibility mentioned above. Arctic Ocean coastal states are unlikely to support this option, however, unless their sovereignty, sovereign rights and jurisdiction in their own maritime zones are in one way or another clearly reflected. This would be especially relevant in case this option is given shape by means of an RFMO or an Arrangement. Negotiation of the CCAMLR Convention ${ }^{99}$ resolved this by including assurances in Article $\operatorname{IV}(2)(b)$ and (c) of the Convention as well as through the "Chairman's Statement" made upon adoption of the Convention. ${ }^{100}$ An alternative could be to create separate bodies (e.g., committees) for coastal state maritime zones and the high seas.

\section{iii. Which states and entities should participate?}

As the discussions on the previous questions have shown, participation is a crucial aspect for other preliminary choices. Which states and entities

98 Cf., "Fish Stocks Agreement", supra, note 10, at Art. 7; Resolution of 20 January 2011, supra, note 84, at para. 22.

99 "Convention on the Conservation of Antarctic Marine Living Resources", Canberra, 20 May 1980, in force 7 April 1982, 1329 United Nations Treaty Series (1983), 47.

100 Included in the Final Act of the "Conference on the Conservation of Antarctic Marine Living Resources, Canberra, 7-20 May $1980^{\prime \prime}$ (on file with the author). 
should and should not participate can be a consequence from another preliminary decision or be a point of departure in its own right. For instance, new bodies and/or instruments that relate exclusively to coastal state maritime zones will only be open to relevant coastal states. The issue of participation is further examined for two concrete options in Subsections IV.2 and IV.3.

\section{iv. Which other factors and considerations need to be taken into account?}

In addition to the overarching need for consistency with international law, preliminary choices may be based on other factors and considerations as well. Paramount among these is the timeframe within which policy and regulatory responses should be established. As fish stocks are expected to become more abundant within coastal state maritime zones before becoming more abundant within the Central Arctic Ocean, the urgency of responses to fishing in coastal waters is undeniably higher. However, responses with respect to the Central Arctic Ocean could still be necessary for precautionary reasons and may be desirable to avoid problems that unregulated fisheries often trigger such as in relation to the allocation of fishing opportunities. Such precautionary, pro-active, and pre-emptive action should nevertheless only be undertaken with due account of the need for cost-effectiveness. Multilateral negotiations to establish full-fledged RFMOs similar to the most recent ones for the South and North Pacific ${ }^{101}$ are by no means warranted for a high seas area where fishing currently does not take place. An Arrangement is therefore a much more suitable option.

Considerations of fairness and equity will play roles in various ways as well. These come to the fore

101 Negotiations for the South Pacific concluded in 2009 with the Convention on the Conservation and Management of High Seas Fishery Resources in the South Pacific Ocean (SPRFMO Convention) Auckland, 14 November 2009, not in force. Negotiations for the North Pacific adopted the English version of the text of the Convention on the Conservation and Management of High Seas Fisheries Resources in the North Pacific Ocean (on file with author) in March 2011, but the Convention will only be opened for signature after the French version has been adopted (information up-to-date as of end November 2011).

102 See supra, note 3, at 50 C.F.R. § 679.7(p).

103 Whether or not on account of the autonomy that Arctic indigenous peoples may have within certain Arctic states. See also Ridgeway, "Issues", supra, note 5, at 432.

104 Arctic Council, "Rules of Procedure", adopted by the Iqaluit Declaration, Iqaluit, 18 September 1998, at Rule 7. within the context of allocating fishing opportunities and sharing conservation burdens between neighboring coastal states, as well as between coastal states and high seas fishing states and entities. Fairness and equity will undoubtedly also be raised in relation to the rights and interests of Arctic indigenous peoples over marine capture fisheries. Notably, the United States' action with respect to its EEZ off Alaska in the Arctic Ocean does not apply to "subsistence fishing." ${ }^{102}$ While the Arctic indigenous peoples dimension could be addressed exclusively at the domestic level, ${ }^{103}$ it might also be dealt with at the intergovernmental level and even be incorporated in the body or preamble of international instruments. In view of the unique role accorded to Arctic indigenous peoples in the Arctic Council through their representation by Permanent Participants, this could be a reason for pursuing options within the Arctic Council as such or within the ACS (see Subsection IV.2).

\section{Options Within the Arctic Council and Arctic Council System}

As the foregoing discussion indicates, a range of options could be undertaken by the Arctic Council or within the ACS. With respect to the Council, this could build on its traditional monitoring and assessment role, for instance through a one-off assessment on Arctic fisheries or the establishment of a new permanent scientific assessment and advisory body on Arctic fisheries (see Subsection III.2). Traditional knowledge of Arctic indigenous peoples could be incorporated through the involvement of Permanent Participants.

A non-legally binding instrument on Arctic fisheries or (Central) Arctic Ocean fisheries would not be precluded by the Council's constitutive instrument. If it were to relate to Arctic fisheries in general, however, it may not be able to provide sufficient specificity to address the gaps identified. Conversely, the five Arctic Ocean coastal states may not support a specific focus on the Arctic Ocean or the Central Arctic Ocean - excluding the NEAFC Convention Area - in view of the special role they claim for themselves there.

A problem for all these scenarios is that only the eight Arctic states are entitled to participate in formal decision-making. ${ }^{104}$ In case the instrument 
were to (also) relate to the Central Arctic Ocean, where the freedom of fishing applies, its effectiveness would benefit from the support of key non-Arctic states and entities. Such support could be ensured through a format or mechanism that allows them to participate in the instrument's negotiation as well as to express their consent to be bound. ${ }^{105}$ Involving only the current non-Arctic state observers would not work. This group consists of six EU Member States (i.e. France, Germany, the Netherlands, Poland, Spain and the United Kingdom) that have transferred most of their competence on marine capture fisheries to the $\mathrm{EU}$, and therefore does not include any key high seas fishing states and entities such as China, the EU, Japan, South Korea, and Taiwan. While all these except Taiwan have applied for observer status, it is by no means clear when and if these applications will be approved. ${ }^{106}$ If all applications were approved, however, involving observers could be an important component of the aforementioned format or mechanism.

In case states were to prefer a legally binding instrument, this could be pursued within the ACS by means of a task force established by the Council but merely operating under its auspices. In this case, the task force could work towards an Arrangement with an institutional component. ${ }^{107} \mathrm{~A}$ fullfledged RFMO seems unlikely, however. All of the observations made above on the spatial scope and participation by non-Arctic states and entities in a non-legally binding instrument of the Arctic Council would apply here as well.

The choice for the words "would [...] benefit from support by key non-Arctic states and entities" above, is intended to flag that not securing their support by means of participation would not necessarily be inconsistent with international law. This is examined further in Subsection IV.3.

Among the advantages of pursuing options within the Arctic Council or the ACS are providing an agreed-upon mechanism for involving Arctic indigenous peoples ${ }^{108}$ and the potential for optimal coordination with other activities of the Council and the ACS, thereby contributing to more successful integrated oceans management. Yet, Arctic states, Permanent Participants, non-Arctic states and entities, and international environmental nongovernmental organizations may support or oppose options within the Arctic Council or the ACS for strategic reasons that have little to nothing to do with Arctic fisheries but are principally related to how they would like the Arctic Council and the ACS to evolve. Reference can be made to the new rules on observers adopted at the 2011 Nuuk Ministerial Meeting, ${ }^{109}$ which may not prove conducive to broader participation.

\section{Stand-alone Instrument on the (Central) Arctic Ocean}

An alternative to pursuing options within the Arctic Council or the ACS would be to develop a standalone instrument for the Arctic Ocean or the Central Arctic Ocean, while excluding the NEAFC Convention Area. As noted above, in view of the need for cost-effectiveness, it seems that an Arrangement - whether legally binding or not - is more appropriate than a full-fledged RFMO. Moreover, if the instrument's spatial scope and measures it contains would be limited to the Central Arctic Ocean as advocated by some, ${ }^{110}$ similar measures or measures with similar effectiveness need to be adopted by Arctic Ocean coastal states for their own maritime zones. ${ }^{111}$ The need for compatibility is particularly evident as it is likely that new fishing opportunities will arise in coastal state maritime zones before on the high seas. An exception may nevertheless be granted to further the rights and interests of Arctic indigenous peoples.

\footnotetext{
105 E.g., modelled on the formats devised for Taiwan in the context of international fisheries law.

106 For a discussion, see Molenaar, "Current and Prospective Roles", supra, note 68.

107 Note that Art. 10 of the Arctic Search and Rescue (SAR) Agreement also contains an institutional component, namely "Meetings of the Parties."

108 It must be noted that Permanent Participants have not yet participated in negotiations on the Arctic SAR Agreement or towards an Arctic instrument on marine oil pollution preparedness and response. As this seems principally due to lack of expertise and resources, the issue of their entitlement to participate has not been addressed.
}

109 See Senior Arctic Officials (SAO) Report to Ministers, Nuuk, May 2011, at Annex 1.

110 See, e.g., Pew Environment Group, "Oceans North International", available on the Internet at <oceansnorth.org/ international $>$ (last accessed on 12 January 2012).

111 The issue of compatibility could also be raised with respect to the NEAFC Convention Area and the remainder of the Arctic Ocean. 
As noted earlier, if the five Arctic Ocean coastal states supported such a stand-alone instrument, they would likely claim a lead role in its negotiation. Once sufficient support exists among the five, they are likely to engage in preliminary consultations. This is understandable as they are all coastal states, and therefore share certain rights and interests. Coastal state consultations would probably continue during actual negotiations. However, assuming that the Arctic five intend to involve other key states and entities, this should occur before drafting has commenced. Participation by other states and entities could otherwise not be regarded as meaningful.

While it is assumed that states and entities other than the Arctic five would be allowed to participate in the negotiation of a stand-alone fisheries instru-

112 Reference can in this context be made to the controversial "Galapagos Agreement," which never entered into force. See "Framework Agreement for the Conservation of the Living Marine Resources on the High Seas of the Southeast Pacific", Santiago, 14 August 2000, not in force, Law of the Sea Bulletin (2001), 70-78, No. 45 (2001). The Agreement has been replaced by the SPRFMO Convention (see supra, note 101) and its current Preparatory Conference. ment and eventually become parties thereto, this assumption could of course be proven wrong. A coastal states-only (inter se) approach would not necessarily be inconsistent with international law. This would only occur if the exercise of the right to engage in high seas fishing by other states and entities would be interfered in ways contrary to international law. At-sea high seas enforcement would be an obvious example. Exercising port state jurisdiction by the Arctic five to ensure compliance with their high seas conservation and management measures by other states and entities could be inconsistent with international trade law as well. Presumably the Arctic five would prefer to avoid these issues as well as the lack of legitimacy associated with coastal state-only approaches. ${ }^{112}$ In a worst-case scenario, such lack of legitimacy might even prompt high seas fishing states or entities to engage in high seas fishing in the Central Arctic Ocean in order to assert their rights as such, even if such fishing would not be commercially viable. Fortunately, the clear commitment to peace, order, and cooperation underlying the Ilulissat Declaration implies also a commitment by the Arctic Ocean coastal states to avoid such a scenario. 